\title{
MAKING A DIFFERENCE? WHY WE NEED A MORE DIVERSE JUDICIARY
}

\author{
Lady Hale \\ Law Centre (Northern Ireland) and SLS Lecture 2005*
}

\begin{abstract}
"I have nothing against innovation but this has never been done before"
\end{abstract}

On this basis, or something very like it, women were excluded from the legal profession until the Sex Disqualification (Removal) Act 1919. But it is now 86 years since women were allowed to join the legal profession and aspire in due course to become judges. It is more than half a century since the first women sat as professional judges in our courts, The very first was Sybil Campbell, who was appointed a metropolitan stipendiary magistrate in 1945. She is nowhere near as famous as Dame Elizabeth Lane, the first woman county court and later High Court judge, and Dame Rose Heilbron, the first woman Recorder and second High Court judge. It is nearly twenty years since women began joining our law schools in equal numbers with men. Yet our judiciary is still predominantly male and pale.

In England and Wales, less than $11 \%$ of our salaried (permanent) judges in the ordinary courts are women. Fewer still belong to an ethnic minority (the published figures do not give the full picture, perhaps because not everyone is happy to have their ethnicity recorded). Your figures in Northern Ireland are rather better, with over $17 \%$ of your salaried judges in the ordinary courts being women. But percentages can be misleading when numbers are small. In both our countries, the situation is worse the higher one climbs in the judicial ranks. You have no women in the High Court or above until you get to me. ${ }^{1}$ Only 10 of our 106 High Court judges are women; one of them is the very first from a black or Asian ethnic minority. Only 2 of our 37 Court of Appeal judges are women, none from an ethnic minority. Since the retirement of Dame Elizabeth Butler-Sloss at the end of last term, none of the four Heads of Division - the Lord Chief Justice, Master of the Rolls, President of the Family Division and Vice-Chancellor - is a woman. And it took until last year for a woman to be appointed to the top court in the United Kingdom - the appellate committee of the House of Lords.

The proportion of women amongst the fee paid (part time) judiciary in both our countries is higher, over $20 \%$, and some find this an encouraging sign of better things to come. But even if all these women go on to become permanent judges, it will take a very long time indeed before the proportion of women on the bench mirrors the proportion of women entering the legal profession. It would be unfair to describe our pale male judiciary also as stale - but it is drawn from a comparatively narrow range of social and

* Given at Queen's University on 17 June 2005.

1 Lady Hale is the first woman to be appointed to the appellate committee of the House of Lords (editor's note). 
educational backgrounds and from a very narrow range of legal professional backgrounds. I am doubly unusual, not only in being a woman, but also in having made my professional name as an academic and public servant rather than as an advocate.

I believe that in all three parts of the United Kingdom, it was largely concern about the lack of diversity - on a variety of measures - in the judiciary which led to calls for reform in the judicial appointments system. This is not to decry the efforts made by Lord Chancellors and their departments to make improvements. But things have really started to move since we have had a Commissioner for Judicial Appointments, both in Northern Ireland and in England and Wales, and Scotland has led the way in having a Judicial Appointments Board. Now you have your own Judicial Appointments Commission, launched this week, and we are in the process of appointing ours. But your Commission, unlike ours, will have a statutory duty to secure, so far as it is reasonably practicable to do so, that those holding judicial office are reflective of the community in Northern Ireland. ${ }^{2}$ You see nothing inconsistent in combining this with a requirement that appointment to judicial office be only on the basis of merit. We seem to have more problems with this in England and Wales. Our Commission will only have to have regard to the need to encourage diversity in the range of people available for selection. ${ }^{3}$

For alongside the dispiriting figures I have quoted, there exists a belief, voiced by some of our most senior judges, that we have one of the best judiciaries in the world - if not the best. Our higher judiciary do indeed score highly on what I call the four 'in-quotients': my colleagues are undoubtedly incorruptible; seriously intelligent; extraordinarily industrious; and fiercely independent. Many, especially amongst their own number, will attribute this to their having had to make their way in a career at the Bar where all these qualities are now essential to success. Others may wonder how closely these perceptions are also linked to more deep-rooted British especially English - unconscious assumptions about who is 'the best': wellbred, well-spoken, well-educated, white males.

Whenever I meet members of the higher judiciary from elsewhere in the world, I am struck by their own high 'in-quotient'. Yet they, of course, do not all fit our stereotype of the white, well-spoken male. And they have usually come from a much wider range of professional backgrounds and experience. A Supreme Court bench (for example in Israel or Spain) may have members promoted from the lower judiciary, or appointed from the Chief Prosecutor's or Attorney General's office and other Government legal service, from the Universities, as well as from private practice. My point is that we seem to be almost the only country in the world where the only lawyers who are thought fit to serve in our highest courts are those who have excelled as advocates in those courts.

Why should it matter that our judiciary is so peculiar if it is of such high quality and even fits the traditional national stereotype of the people likely to have that quality? One answer is that times have changed: the country has

2 Justice (Northern Ireland) Act 2004 s.3.

3 Constitutional Reform Act 2005 s.64(1). 
changed and people's expectations have changed. Another is that judging has changed.

In the early decades of the twentieth century, many appointments to the Bench were overtly political. Yet apparently this was not hugely controversial, partly at least because the work of the judges was not seen as political. They administered the criminal law, presiding over jury trials and sentencing those found guilty. They also decided civil disputes, but in nothing like the same numbers as they do today. In the $1950 \mathrm{~s}$, according to Robert Stevens,

"the Chancery judges were such a disagreeable group that litigation in that Division had virtually dried up".

The judicial work of the House of Lords was mostly devoted to 'big money' cases. We recently did a trawl of the cases upon which Lord Cohen, the first Jewish Law Lord, sat from 1951 to 1961. These were dominated by tax, commercial, company and planning cases, with only a smattering of cases which might affect the lives of ordinary men and even fewer that might affect the lives of ordinary women. There was only one recognisably civil liberties case and no judicial review cases at all.

The quality and quantity of our work at all levels has changed dramatically since then. Three things have contributed to the greater constitutional and 'small p' political significance of the work of the higher judiciary:

The first is European Union membership. In practice, this does not provoke a great deal of litigation as opposed to regulation, but the litigation it does provoke has a new quality. Some of the rights of the citizens of EU countries have to be given direct effect in member states even if they have not been legislated by the domestic Parliament, or are even incompatible with domestic legislation. A recent example is our decision ${ }^{4}$ that a postoperative trans person had to be treated for employment purposes as a member of the sex to which she now belonged. This was because of a decision of the European Court of Justice ${ }^{5}$ interpreting the Equal Treatment Directive 76/207/EEC. It had nothing to do with a later decision of the European Court of Human Rights ${ }^{6}$ on the right of a trans person to marry in their reassigned gender.

The second, and numerically far more important development, was the explosion in judicial review of administrative action. There were some landmark House of Lords decisions in the 1960s (such as Padfield v Ministry of Agriculture [1968] AC 996 and Anisminic v Foreign Compensation Commission [1969] 2 AC 147); but things really took off in the 1970s when a new unified procedure replaced the old prerogative writs of prohibition, certiorari and mandamus and the declaration procedure. The purpose did not change. The Court is not allowed to question the merits of an executive decision lawfully taken. Its task is to ensure that the decision is not illegal, irrational or unfairly taken. But the public increasingly saw it as a possible

4 Chief constable of West Yorkshire Police v A (No 2) [2004] UKHL 21; [2004] 2 WLR 1209.

$5 \quad P$ V $S[1996]$ ICR 795.

6 Goodwin v United Kingdom (2002) 35 EHRR 447. 
way to challenge decisions they did not like and an ingenious legal profession persuaded the judges to develop those concepts so that the chances of success became much greater than they had previously been.

The third is of course the Human Rights Act 1998, incorporating the European Convention into United Kingdom law. This makes several important changes. First it gives us all positive new rights against the State. Public authorities are not allowed to act in a way which is incompatible with our Convention rights. If they do the courts have new powers to put it right unless the public authority was bound by United Kingdom statute to do what it did. Second, the courts have a new duty to read and give effect to all United Kingdom legislation so as to be compatible with the Convention rights. This can affect private individuals as well as public authorities. Third, if a statute cannot be read compatibly, the Court may not strike it down but the High Court may declare it incompatible. The Government is then bound by its international obligations to do something about it, however reluctantly. The best known example is the Belmarsh case, $A$ v Secretary of State for the Home Department [2004] UKHL 56; [2005] 2 WLR 87 which led to the Prevention of Terrorism Act 2005.

These three developments have certainly made the work of the higher courts entirely different from what it was in Lord Cohen's day. But that is among the more rarefied heights of the judiciary. Other developments have made the legal system much more accessible to ordinary members of the public, and increased the range of issues that can be brought to court, many of which undoubtedly have a social and 'small p' political dimension.

For example, the post-war welfare state saw access to justice in much the same way as it saw access to other social services, as something which should be made available to those who could not afford to pay for it on similar terms to those who could. By access to justice was meant access to the legal services which would enable people to gain access to the courts. The legal aid scheme had a comparatively generous means test and its scope was progressively extended until the 1970s. In the 1970s all the talk was of 'unmet legal need'; it had yet to be acknowledged that a demand-led service access to which was controlled largely by its providers might be unsustainable. People were thus encouraged to think that they could take their cases to court and did so. Even now that everything about the legal aid scheme has been curtailed, the idea that litigation should be within the grasp of ordinary people with ordinary grievances is deeply engrained.

Another factor, not unrelated to the first, is the huge increase in family breakdown and family litigation. Divorce has been made available to all, rather than the preserve of the few. Family litigation is big business. Perversely, the public have responded with an increasing reluctance to get married at all, whether or not they have children. But they still separate and feel the need to litigate. The corresponding empowerment of women has recently been matched by the emergence of a fathers' rights movement. Recent demonstrations on behalf of separated fathers have clearly shown how sensitive and small p political this jurisdiction can be.

The access to justice theme is taken further by all the new tribunal jurisdictions which have been created; some of these are in the private sector, redressing the inequalities of bargaining power in the relationships between 
landlord and tenant or employer and employee; most are in the public sector, giving the claimant or applicant an avenue of appeal against administrative decisions, for example on benefits, housing, immigration or asylum. Some of these jurisdictions are now enormous and at least as important in the lives of ordinary people as the regular courts of law. The proportion of women holding judicial office in them is higher than in the ordinary courts. But as a matter of principle they all have a route into the ordinary courts of law, usually through statutory rights of appeal, but also through judicial review.

In this changed world, where law is not the exclusive domain of commerce and the better off, it matters much more who the judiciary are and how they are perceived. All common law countries, which tend to recruit their judges from amongst their higher court advocates, tend to face the same difficulties in achieving a more reflective judiciary. But the common law country which has made the most serious attempts to do this is Canada. In the last two decades, their proportion of women judges has changed from something very like our present proportion to something over a quarter at all levels of the federal and provincial judiciary. They even have a female Chief Justice, Beverley McLachlin, something which I still find difficult to envisage here. She has given four reasons ${ }^{7}$ why she believes that increased representation of women on the bench has changed and will continue to change their legal system for the better:

"First, I believe that women on the Bench are necessary to the public confidence of our judicial systems. From the point of view of the public's perception, the presence of women on the Bench makes the legal system less alien and more relevant to the female half of our population. The courts of our country should no longer be viewed as all male preserves into which females and minorities venture at their peril. The paternalistic aura which once characterised our courts is fast diminishing. Our courts have become, more than ever before in history, the people's courts. . . . The reality is that many people, particularly women, may feel less than complete trust in a system composed exclusively or predominantly of middleaged white men in pinstriped trousers. They will question whether such a court can reflect the various viewpoints and values of an increasingly pluralistic society. ..."

This is closely akin to the conclusion I reached in a similar paper in $2000 .^{8}$ In a real democracy, judges can no longer claim legitimacy solely on the basis of their legal expertise and social superiority. They have to reflect the fact that they are servants of a diverse society all of whose members are equally valued. Chief Justice McLachlin continues with a related but distinct consideration:

"The second reason I think it is important to have women on the Bench is symbolic. In a world where one of the primary functions of the judiciary is to promote equality and fairness, it

7 At a seminar run by the Association of Women Barristers, House of Commons, London, United Kingdom, Wednesday, July 2, 2003.

8 'Equality and the Judiciary: Why should we want more women judges?' [2001] PL 489, delivered to the Society of Legal Scholars annual conference in 2000. 
would be anomalous if the very instrument charged with that goal should itself exclude women from its ranks ..."

Of course, it has always been the role of the judiciary to promote procedural fairness. The idea that they might also promote substantive fairness and equality is much more recent and by no means universally accepted. Chief Justice McLachlin is speaking of a legal system which has had a Charter of Fundamental Rights and Freedoms since 1982 (and statutory protection for human rights and fundamental freedoms for much longer than that). But our own legal system has been promoting social justice at least since the institution of the welfare state and is now turning its attention to fundamental human rights. Article 1 of the Universal Declaration of Human Rights declares that 'all human beings are born free and equal in dignity and rights'. This is often demonstrably untrue in fact, but it is still an important principle and aspiration. I do believe that there is some symbolic value in the fact that our doorkeepers now shout 'their lordships and her ladyship' when the law lords appear on the committee corridor to file into the appellate committee room in the House of Lords.

Even those who are still having difficulty with the principle of equal dignity would probably now accept Chief Justice McLachlin's third reason:

"The third reason for putting women on the Bench is utilitarian. Simply put, it represents a sound use of human resources. It seems to me that modern societies cannot afford to lose the intellectual power and energy of half the population. ... Our society is increasingly complex, our birth rates are low. We need the wisdom, not only of wise men, but of our wise women."

On the whole, the idea that all should have an equal opportunity to compete in the public arena on the basis of merit is now widely accepted. It still leaves plenty of room for argument about what we mean by merit and how it should be recognised.

Her last reason is more controversial. It is that women judges might actually make a difference:

"The fourth and most important reason why I believe we need women on our Benches is because we need the perspectives that women can bring to judging."

Both Dr Kate Malleson ${ }^{9}$ and I have argued that we should not expect women judges to 'make a difference' in the sense that they are likely to make different decisions from men. Women are as diverse as men in their characters and attitudes. We are all lawyers and judges first and men or women second. We all swear the same judicial oath,

'to do right to all manner of people, according to the laws and usages of this realm, without fear or favour, affection or ill will.' In most cases, according to Mary Jean Coyne, Chief

9 'Justifying Gender Equality on the Bench: Why Difference Won't Do' (2003) 11 Feminist Legal Studies 1. 
Justice of Minnesota, 'A wise old woman and her wise old man reach the same conclusions.'

More fundamentally, does not the idea that the gender of a judge might make a difference strike at the very idea of judicial neutrality? Many people think of the law as a collection of clear rules and principles which will lead to a determined outcome once they are applied to the proven facts of a given case. This is not in fact how the common law works, as the great Lord Reid explained in his famous lecture to the Society of Public Teachers of Law in 1971:10

"There was a time when it was thought almost indecent to suggest that judges make law - they only declare it. Those with a taste for fairy tales seem to have thought that in some Aladdin's cave there is hidden the Common Law in all its splendour and that on a judge's appointment there descends on him knowledge of the magic words Open Sesame. Bad decisions are given when the judge has muddled the password and the wrong door opens. But we do not believe in fairy tales any more."

And yet Erica Rackley ${ }^{11}$ argues that people may need to think of the law as a simple set of clear rules and the judges as their neutral interpreters:

“. . . maybe we do need to believe in fairy tales. Maybe ... a belief in the superhero judge who comes with a built in programme, a game plan to ensure a coherent and certain outcome consistent with the values and premises of the particular political tradition he is there to serve and preserve is intrinsic to our notion of judging. . . The merest glimmer of recognition that judges may be political actors with substantial power and opportunity to enact their personal political preferences surely threatens to render unstable the whole edifice of the law ... Hence the importance of preserving the mythological dimension of the adjudicative process, ensuring its distance from the concerns of mere mortals. We can imagine the judge in no other way. He has to be seen as 'supra' human. We even make him dress up in his own kind of cape and mask - well wig - his own 'superhero' outfit."

The wig we make the judges wear is, of course, a man's wig. The very idea of a judge as a real human being with a life of her own will threaten this super-hero image. Just as Henry Cecil said that we should not be able to imagine a judge having a bath, we should not be able to imagine her doing the washing up (I wish). Rackley goes on to compare the woman judge with Andersen's little mermaid - who traded her beautiful voice for legs so that she could join her handsome prince on dry land and then found that he was no longer interested in her:

10 'The Judge as Lawmaker' (1972) 12 JSPTL 22.

11 In her wonderful paper on 'Representations of the (woman) judge: Hercules, the little mermaid, and the vain and naked Emperor' (2002) 22 Legal Studies 602, 616. 
"She [the woman judge] too remains cast as a mermaid. Her physical appearance threatens to upset aesthetic norms; her presence is an inescapable irritant, simultaneously confirming and disrupting the established masculinity of the bench. As such, the woman judge is almost a contradiction in terms. She is so deviant that she is inevitably subject to an irrepressible desire to conform. Like Andersen's mermaid, she is induced to deny herself and sell her voice; her dangerous siren call is silenced and in the silence difference is lost."

This may strike a chord with those who remember our first woman High Court judge, Dame Elizabeth Lane, but it certainly would not with those who remember our second, Dame Rose Heilbron.

But although I argue that we should not expect a woman judge to make a difference, I do believe that having women judges can actually make a difference. This is on at least two levels, style and substance. We should not underestimate the importance of different styles of judging. They have a contribution to make to the reflective and symbolic functions of diversity mentioned earlier. We have to challenge the notion that the only person who can be taken seriously as a neutral and fair-minded person is the judicial equivalent of a tall man in a suit. We have to establish the claims of people who are recognisably women, and of people of colour and people with disabilities, to be regarded as serious and responsible. We have to reflect ourselves in the way that we speak. I speak, as I said in a recent opinion, as "a reasonable but comparatively weak and fearful grandmother" with as much right to be heard as the stronger and braver grandfathers around me. ${ }^{12}$ We also have to stop dressing up as old men and prove that we can do the job properly without the disguise. Fortunately, in the House of Lords we have discarded the superhero outfit and dress more or less as ourselves.

Window dressing is important, as every retailer knows, but it is also desirable to improve the quality of the products on sale. We might expect a more diverse judiciary also to have some impact upon the substance of the law. As Chief Justice McLachlin put it:

“. . . jurists are human beings, and, as such, are informed and influenced by their backgrounds, communities, and experiences. For cultural, biological, social and historic reasons, women do have different experiences than men."

Orally, she put it more graphically:

"We lead women's lives: we have no choice."

The experience of leading those lives should be just as much part of the background and experience which shapes the law as the experience of leading men's lives has been for centuries. Of course, the whole idea that a judge's experience may shape the law calls into question the role of a judge in making the law. We may not believe in the declaratory 'fairy tale' any more, but we certainly believe that there are limits to judicial creativity. This is a large subject upon which a great deal has been written and will be written in future. We are at the moment considering whether it is possible

$12 R \vee Z$ [2005] UKHL 22, [2005] 2 WLR 709, at para.73. 
for the House of Lords to overrule a previous decision for the future only, rather than with retrospective effect, as is the general rule. Prospective overruling does, of course, look far more like changing the law than simply divining what the law is by the extrapolation of known rules and principles. (That is why the liberal judges of the United States Supreme Court were prepared to countenance it in the 1960s, whereas the present court is not.) In general, while we recognise that there are situations in which the courts can develop the common law to meet changing circumstances, we draw the line at judicial law reform - that should be left to Parliament. And where Parliament has already spoken, the judicial task is one of interpretation - but even here there are often choices to be made. So I want to illustrate the difference that diversity might make by two examples, one of a development in the common law, and the other of a development in statutory interpretation.

The great majority of judgments which I have written or spoken could just as easily have been written or spoken by a man. But there is one exception. In Parkinson v St James and Seacroft University Hospital NHS Trust [2001] EWCA Civ 530, [2002] QB 266, I tried to put into words the experience of bearing and rearing a child from the woman's point of view. Parkinson was an example of a knotty problem in an almost completely judge-made area of the law: what should be the scope of a doctor's liability if she negligently fails to sterilise a man or a woman properly so that a child is conceived and born whom the parents never intended to have and had good reasons for not wishing to have? Should the doctor (or rather the doctor's employers or insurers) have to pay the full cost of bringing that child up? Or should the parents have to bring into account the incalculable benefit which such a child can bring to them and to society? And what if the child is disabled, so that he costs more to bring up than other children do? And what if the mother is disabled, so that she is unable to bring up the child without a great deal of extra help?

After initial wobbles, the English Court of Appeal decided, applying entirely orthodox principles, that the doctor had to pay. She undoubtedly had a duty to take reasonable care to perform an effective sterilisation or warn that it might not be so. The entirely foreseeable result of failing to take such care was an unwanted pregnancy. The pregnancy brought with it identifiable consequences which would ordinarily sound in damages. The benefits could not be quantified so could not be taken into account. The House of Lords, in MacFarlane v Tayside Health Board [2000] 2 AC 59, eventually took a different view. By then they had developed a new doctrine to limit the scope of liability in negligence. They had done this largely because they had extended the scope of the tort to cover financial loss as well as physical harm to persons or property. The duty to take care now extends only so far as it is fair, just and reasonable to impose it. ${ }^{13}$ Hence the House held that it was fair, just and reasonable to compensate the mother for the pain and suffering involved in the pregnancy and childbirth and for the immediate costs associated with this. But it was not fair, just and reasonable to compensate the parents for the full cost of bringing up the child they had never meant to have. In Parkinson, in the Court of Appeal, we held that the parents could

13 See Caparo Industries plc v Dickman [1990] 2 AC 605. 
nevertheless have the extra costs involved in bringing up a disabled child. And in Rees v Darlington Memorial Hospital [2003] QB 20 we held that a blind mother could have the extra costs involved in bringing up the child she had sought to avoid having precisely because she did not feel able to bring one up herself. Three of a seven judge House of Lords ${ }^{14}$ held that we were right: the McFarlane decision had only been concerned with the upbringing of a healthy child by healthy parents. Four of them held that we were wrong: but they nevertheless acknowledged that negligently to cause a woman to conceive and bear a child she never meant to have was an invasion of her bodily autonomy which should be marked by a conventional sum in compensation, which they put at $£ 15,000$ : not nominal but not the full cost or even the extra cost of bringing up the child. Where this leaves the Parkinson decision is not entirely clear.

Although in one sense I lost the battle, there is another sense in which I believe that I won the war. The tendency had been to conceptualise the damage caused by having an unwanted child in financial terms - the financial costs of feeding, housing, clothing and educating her. I tried to reframe the damage in terms, first of the invasion of the mother's right to bodily integrity and autonomy, and second in terms of the responsibility which having any child entails $24 / 7$ until the child is old enough to fend for herself.

Even when it comes to statutory interpretation there are choices to be made, in which the different perspectives of the different judges may also be helpful. A good example is the recent fate of paragraph 2 of the Rent Act 1977 as amended by the Housing Act 1988. This gives preferential rights to succeed to a Rent Act tenancy to the surviving spouse of a deceased tenant and also to a person who was "living with the deceased tenant as his or her wife or husband" at the date of death. It gives less preferential rights to a "member of the deceased tenant's family" who was living there at the date of death. So how should the law treat the surviving partner in a homosexual relationship?

There is no doubt that when the concept of a member of the deceased tenant's family was first enacted in 1920 Parliament could not possibly have intended that it would cover the surviving partner in a homosexual relationship. Sodomy and gross indecency were still serious criminal offences. But in Fitzpatrick v Stirling Housing Association [2001] 1 AC 27, a majority of the House of Lords held that it now did so. They employed the principle that a statute is 'always speaking', so that a word which would not have applied to this situation when it was first enacted had to be interpreted in the light of contemporary social circumstances. This in itself was quite a bold decision, but their lordships stopped short of holding that the survivor had been living with the tenant as his or her wife or husband.

Yet in Ghaidan v Godin-Mendoza [2004] UKHL 30; [2004] 2 AC 337, we felt able to take that further step. We found that Parliament had now told us to do so by enacting the Human Rights Act. Article 8 of the European Convention guarantees the right to respect for a person's home. Article 14 requires that the enjoyment the Convention rights and freedoms be secured

14 [2003] UKHL 52; [2004] 1 AC 309. 
without discrimination on grounds such as race, sex, etc. This does not mean that everyone is entitled to a home. But it does mean that if the State steps in to protect the home, it must not discriminate unjustifiably in the classes of people to whom it gives such protection. We could see that there might be a good reason to discriminate between married and unmarried couples, but we could not see any relevant difference between unmarried heterosexual and unmarried homosexual couples for this purpose. Nor could we see any justification for treating one less favourably than the other. We now have a duty to interpret legislation, if possible, so as to be compatible with the Convention rights even if this is not accordance with what Parliament originally intended. Was it possible to interpret the words 'as his or her wife or husband' to include a homosexual partner? One of us thought not: the words 'wife' and 'husband' necessarily connote having a partner of the opposite sex. The rest of us thought that it was: the law no longer ascribes defined roles to husband and wife, so we would be spared the problem of working out which was which, and could simply look for the necessary qualities of permanence, commitment and inter-dependence which make a relationship marriage like.

I am not suggesting that my sex had much to do with this. But an awareness of gender and discrimination issues may have had something to do with it, as may a background in family law and the experience of sitting as a family judge. When I speak of diversity on the bench, I am not only speaking of diversity in the obvious characteristics of sex and ethnicity, but also of diversity in legal experience and expertise.

The two examples I have given show how both the Court of Appeal and House of Lords can play an important part in making and shaping the law. They are both collegiate bodies. The Court of Appeal sits usually in threes, the House of Lords in a minimum of five, and sometimes seven or nine. Efforts are made to secure a suitable balance of expertise in the Court of Appeal. Efforts are made to secure an appropriate ethnic balance in the House of Lords, in the sense of appropriate representation from all three constituent parts of the United Kingdom. But otherwise few efforts seem to be made to ensure an appropriate balance of expertise in the House of Lords: otherwise it would have been taken for granted that there should be crime, public law and family law specialists there at all times.

In my view the new Supreme Court, like other Supreme Courts the world over, should aspire to a greater mix of gender, ethnicity and legal experience and expertise. None of this is incompatible with appointment on merit: that has always depended upon how you define and recognise merit. The Canadians found that in order to secure a more diverse judiciary they had to confront the common law's traditional definition of merit - outstanding ability as an advocate at the highest level. That traditional definition is closely related to the ease with which those who have had traditionally had a dominant role in the selection process can identify the people who have it. In other words, 'we all know who the good people are'. They are all, of course, excellent people. But I share Lord Falconer's view that I cannot possibly be the first woman lawyer who has been (if I am) good enough to join them. I was merely the first who was visible to them.

So if we are to take serious steps towards a more diverse judiciary, we need to do three things. The first is to redefine 'merit': we have to look for the 
best and brightest lawyers, with the right mix of skills and qualities, from all walks of legal life, not just from the ranks of the higher advocates or litigators. The second is therefore to take positive steps to spread the net wider and to encourage more people to make themselves visible to the appointing bodies. And the third is to introduce proper procedures for making those appointments: procedures that would be recognised in the professional world outside the law as reflecting the best equal opportunities practice. But we do also need to retain the flexibility to be a little bold.

The arguments for this sort of diversity, especially at the highest law-making judicial level, are not unlike the arguments for selecting juries from a fair cross section of the community. The United States Supreme Court made much the same point in Ballard v US (1946) 329 US 187, when deciding that a jury panel composed predominantly of men was not a fair cross section of the community:

"The thought is that the factors which tend to influence the action of women are the same as those which influence the action of men - personality, background, economic status and not sex. Yet it is not enough to say that women when sitting as jurors neither act nor tend to act as a class. Men likewise do not act as a class. But if the shoe were truly on the other foot, who would claim that a jury was truly representative of the community if all men were intentionally and systematically excluded from the panel? The truth is that the two sexes are not fungible; a community made up exclusively of one is different from a community composed of both; the subtle interplay of influence one on the other is among the imponderables. To insulate the courtroom from either may or may not in a given cause make an iota of difference. Yet a flavour, a distinct quality is lost if either sex is excluded. The exclusion of one may indeed make the jury less representative of the community than would be true if an economic or racial group were excluded."

A similar point was made by Benjamin Cardozo in his seminal lectures on judging first published in 1921: ${ }^{15}$

"The eccentricities of judges balance one another. One judge looks at problems from the point of view of history, another from that of philosophy, another from that of social utility, one is a formalist, another a latitudinarian, one is timorous of change, another dissatisfied with the present; out of the attrition of diverse minds there is beaten something which has a constancy and uniformity and average value greater than its component elements."

So I have absolutely no intention of turning into the little mermaid. I have every intention of doing my bit to contribute to the attrition of diverse minds.

15 See The Nature of the Judicial Process, Yale University Press, 1961, p.177. 